\title{
Studies on the vaginal plug of the Japanese greater horseshoe bat, Rhinolophus ferrumequinum nippon*
}

\author{
Y. K. Oh†, T. Mōri and T. A. Uchida \\ Zoological Laboratory, Faculty of Agriculture, Kyushu University, Fukuoka 812, Japan
}

\begin{abstract}
Summary. The vaginal plug of the Japanese greater horseshoe bat is composed of an outer, thick, hard and homogeneous layer originating from the stratum disjunctum of the vaginal mucosa and a thin, soft and opaque central core containing accidentally trapped dead spermatozoa. The vaginal plug appeared to be expelled just before or after ovulation in spring. Immediately after copulation in autumn, uterine spermatozoa were dead but few leucocytes were present. As time passes after copulation, however, the infiltration of leucocytes into the uterus increased gradually, and extensive leucocytic phagocytosis of dead spermatozoa occurred during hibernation.
\end{abstract}

\section{Introduction}

In the greater horseshoe bat (Rhinolophus ferrumequinum) spermatozoa are stored in the oviduct ( $R$. $f$. insulanus: Racey, 1975, 1979), particularly in the caudal isthmus ( $R$. $f$. nippon: Möri, Oh \& Uchida, 1982). Since the first discovery of the massive vaginal plug in a rhinolophid bat (Fries, 1879), most authors have referred to the plug as a site of sperm storage and assumed that the spermatozoa it contained were alive but inactive. However, Racey (1975) showed histologically that all the spermatozoa found there are dead. The plugs of rhinolophid bats have been considered to be largely composed of mucus (Rollinat \& Trouessart, 1897) or secretions of the glandular urethralis (Matthews, 1937; Gaisler, 1966) but few attempts have been made to elucidate their structure. Little attention has been paid to the elimination of spermatozoa from the reproductive tract of bats. In some species, leucocytic phagocytosis of spermatozoa in the uterus $(R$. ferrumequinum: Austin, 1960; Miniopterus schreibersii fuliginosus: Uchida \& Mōri, 1974; Mōri \& Uchida, 1980) and epithelial engulfment in the oviduct (Pipistrellus abramus: Mōri \& Uchida, $1974 ; R$. f. nippon: Mōri et al., 1982) is probably involved. This study was carried out to investigate the fate of spermatozoa found in the female reproductive tract of the greater horseshoe bat with particular reference to the structure and origin of the vaginal plug.

\section{Materials and Methods}

A total of 28 (20 adults and 8 juveniles) female Japanese greater horseshoe bats ( $R$. $f$. nippon) were collected at caves in the Fukuoka, Kumamoto and Yamaguchi Prefectures during the period from immediately before autumnal copulation to just before spring ovulation in 1969-1980 (Table 1). Of 10 adults captured in April, 7 were injected subcutaneously at once with 5 i.u. PMSG (Teikoku-zōki Pharmaceutical Co., Ltd, Tokyo), followed 48 h later by 2 i.u. hCG (Mochida Pharmaceutical Co., Ltd, Tokyo), and killed $24 \mathrm{~h}$ after the hCG.

* Reprint requests to Professor T. A. Uchida.

$\dagger$ Present address: Biological Laboratory, Faculty of Natural Science, Yonsei University, Wonju College, Wonju 220 , Korea. 
Table 1. Month collected, reproductive stage and number of the adult female Japanese greater horseshoe bats examined

\begin{tabular}{|c|c|c|c|c|}
\hline \multicolumn{2}{|c|}{ October (before hiberation) } & \multirow{2}{*}{$\frac{\text { January (in hibernation) }}{\begin{array}{c}\text { Copulated but } \\
\text { no ovulation }\end{array}}$} & \multicolumn{2}{|c|}{ April (at arousal) } \\
\hline No copulation & $\begin{array}{l}\text { Just after } \\
\text { copulation }\end{array}$ & & $\begin{array}{l}\text { Just before } \\
\text { ovulation }\end{array}$ & $\begin{array}{l}\text { Just after } \\
\text { ovulation }\end{array}$ \\
\hline 4 & 4 & 2 & $6^{*}$ & $4 \dagger$ \\
\hline
\end{tabular}

The bats were killed by decapitation or perfused under ether anaesthesia through the dorsal aorta with $3 \%$ glutaraldehyde in $0.2 \mathrm{M}$-phosphate buffer $(\mathrm{pH} \mathrm{7.4)}$. The reproductive organs and the vaginal plugs (cut into small pieces) were fixed in cold $3 \%$ glutaraldehyde for $4 \mathrm{~h}$, then washed thoroughly in the same buffer, and further fixed with $1.3 \%$ osmium tetroxide in the same buffer, dehydrated with acetone and embedded in Epon 812 . Thick sections $(1.5 \mu \mathrm{m})$ for light microscopy were stained with $0.5 \%$ toluidine blue. Thin sections $(\sim 60 \mathrm{~nm})$ for electron microscopy were doubly stained with uranyl and lead acetate before examination in an Hitachi HS-9 electron microscope $(75 \mathrm{kV})$. The reproductive organs from 3 bats were fixed in $10 \%$ formalin, embedded in paraffin wax and stained with Harris' haematoxylin and eosin.

\section{Results}

\section{Morphology of the vaginal plug and its expulsion}

In this horseshoe bat the stratified squamous epithelial cells of the vaginal mucosa began to thicken before the onset of oestrus and proliferation accelerated just after copulation in mid-or late October, to give extensive cornification. Consequently, the adult vagina was characterized by a

\section{PLATES 1-3}

Abbreviations: A, acrosome; Cc, Central core; Cp, cytoplasmic process; D, desmosome; Dd, deformed desmosome; Gc, glandular cell; L, leucocyte; Lp, lamina propria; M, mitochondrion; $\mathrm{Mi}$, microvilli; $\mathrm{Mp}$, middle piece; $\mathrm{N}$, nucleus; $\mathrm{O}$, ovary; Os, outer structureless layer; $\mathrm{P}$, principal piece; Sb, stratum basale; Sc, stratum corneum; Sd, stratum disjunctum; Sh, sperm head; Sm, stratum malpighii; Ss, stratum spinosum; St, sperm tail; $T$, tonofilament bundle; $U$, uterus; Ug, uterine gland; Ul, uterine lumen; V, vagina; Vw, vaginal wall.

\section{PLATE 1}

Figs 1 and 2. Comparison of dorsal view of the female reproductive organ between an adult with the vaginal plug and a juvenile collected in April (Fig. 1), and lateral view of the same adult sample as in Fig. 1 and a freshly expelled vaginal plug from another specimen (Fig. 2).

Fig. 3. Light micrograph of a cross-section of the adult vagina in Fig. 1, showing the vaginal plug consisting of an outer thick and structureless layer and a thin central core. Harris' haematoxylin and eosin.

Fig. 4. Light micrograph of a cross-section of the vaginal mucosa in another bat just before ovulation, showing a successive change in cornification of the stratified squamous epithelium. Toluidine blue.

Fig. 5. Electron micrograph of the polyhedral cells of the stratum spinosum in Fig. 4. showing many cytoplasmic processes with desmosomes from which bundles of tonofilaments arise. Inset: desmosomes at higher magnification.

Fig. 6. The cells of the stratum disjunctum in Fig. 4, showing the gradual transformation to the outer structureless layer of the vaginal plug. Inset: deformed desmosomes, at higher magnification, with an unusually thick osmiophilic band in the intercellular clefts. 

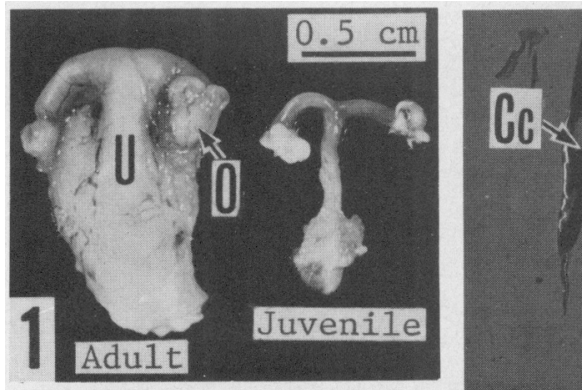

Os
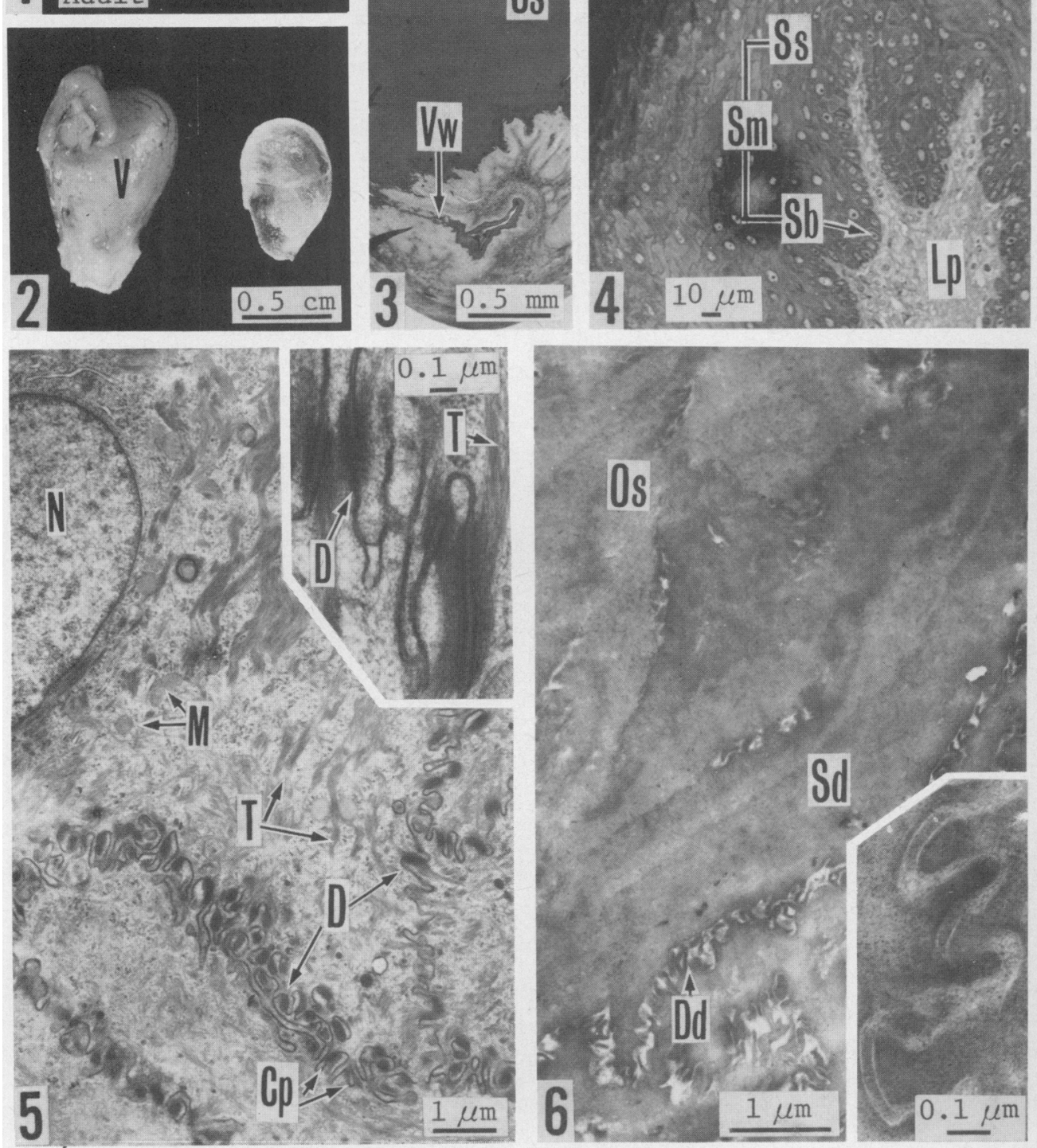
PLATE 2

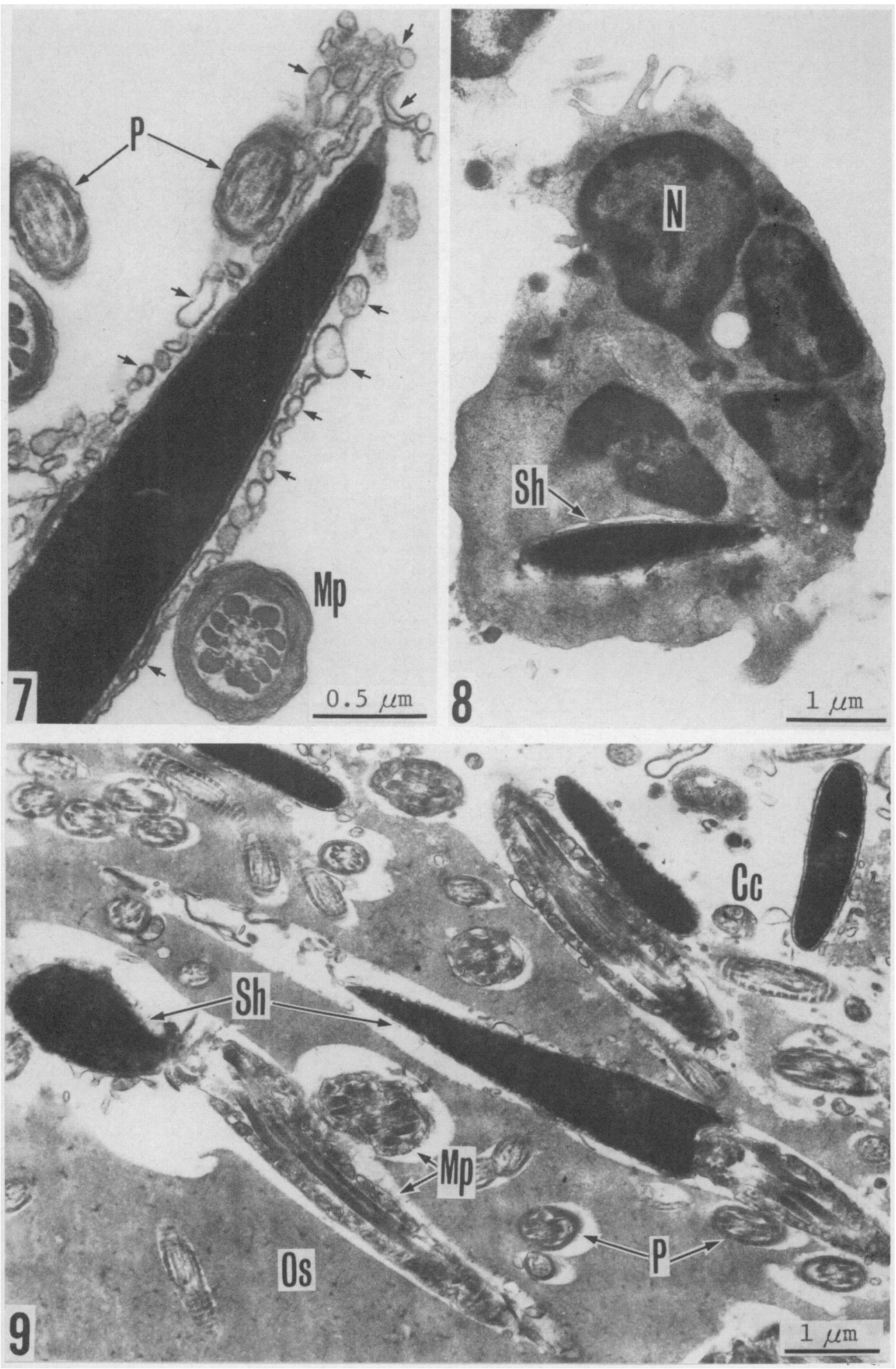


PLATE 3
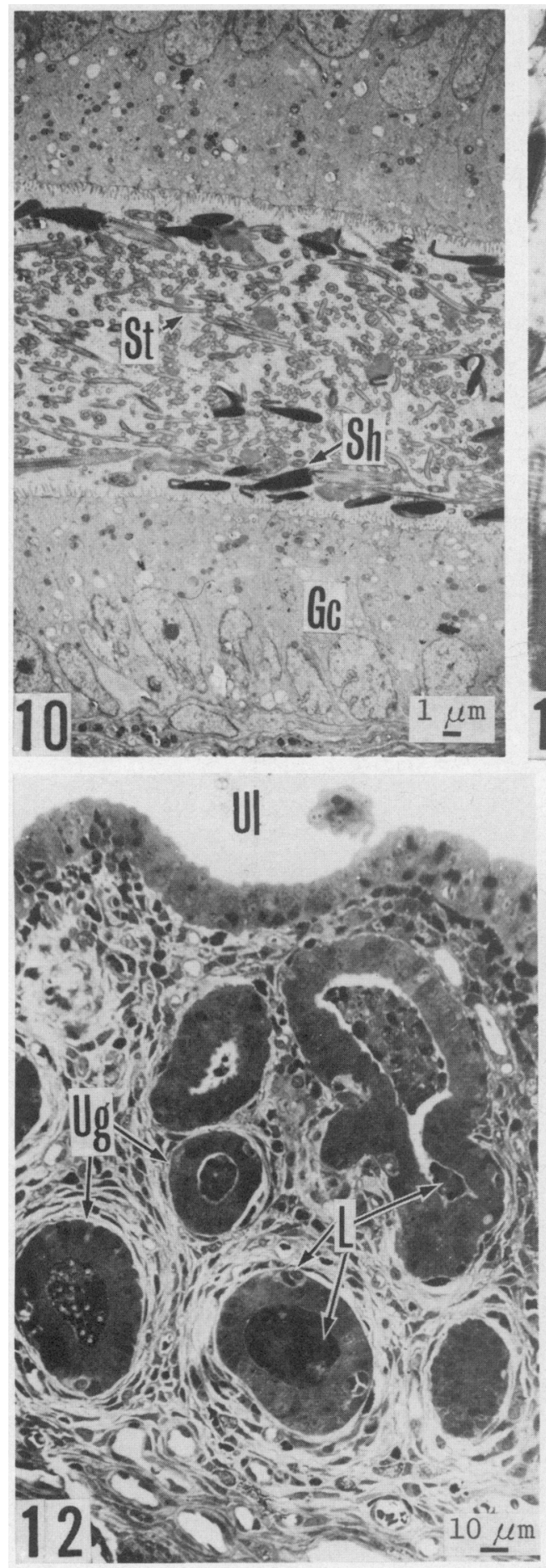

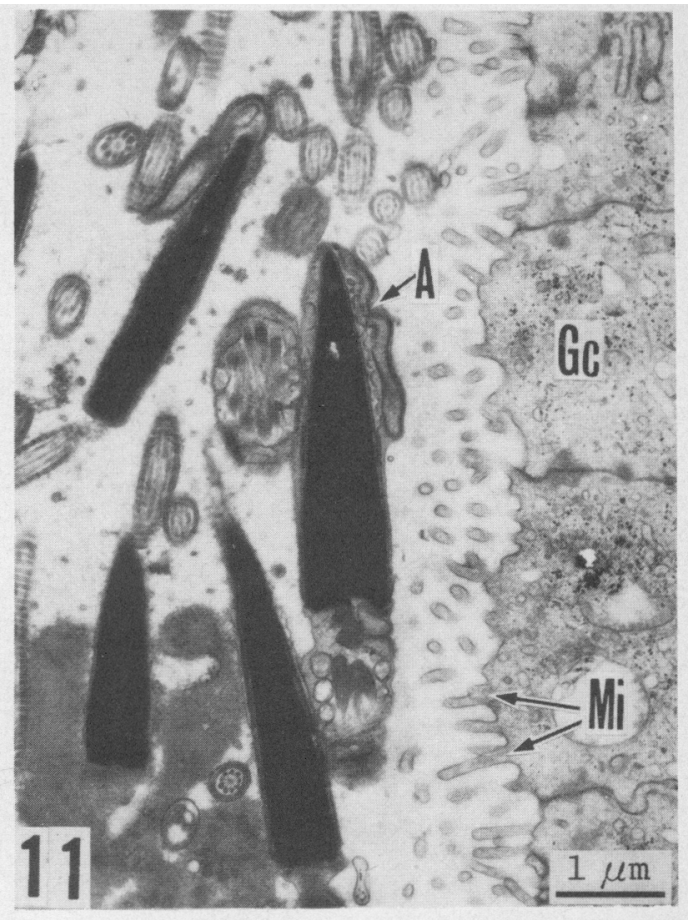

is.

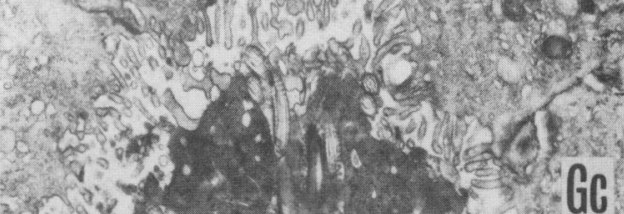

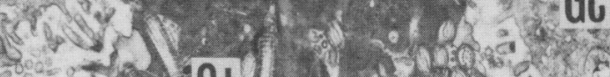

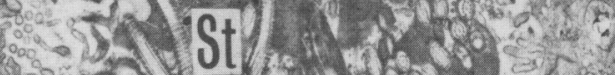

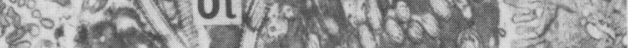

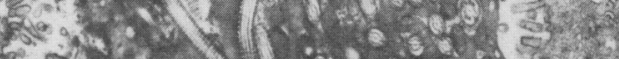

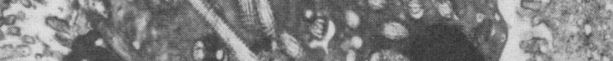

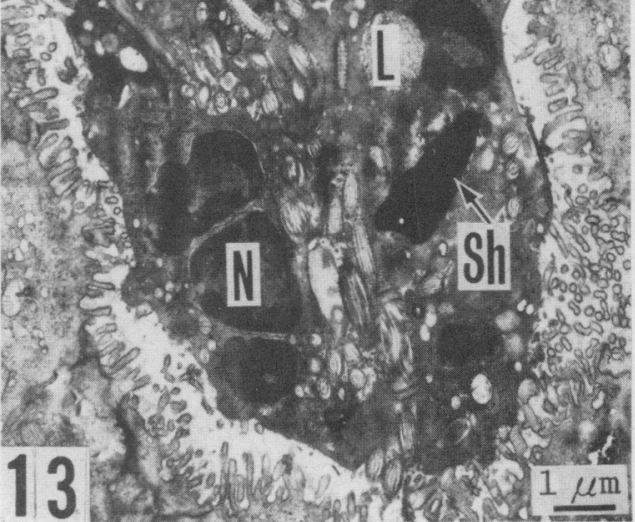


conspicuous enlargement forming a bulky ventral pouch (about $8.4 \mathrm{~mm}$ long, $5.8 \mathrm{~mm}$ wide and $5.8 \mathrm{~mm}$ deep) occupied by the vaginal plug (about $6.9 \mathrm{~mm}$ long, $3.3 \mathrm{~mm}$ wide and $4.5 \mathrm{~mm}$ deep), while juveniles in April had no vaginal pouch (P1. 1, Figs 1 and 2).

The freshly expelled vaginal plug was a clear, hard, ellipsoid body (Pl. 1, Fig. 2) with a thin opaque white core; after post-fixation with osmic acid, the outer layer became black although the colour of the central core hardly changed. In the light microscope the plug appeared to consist of an outer thick and structureless layer, and a central core containing a coagulum formed from the secretions of the male accessory glands and a mass of packed spermatozoa (P1. 1, Fig. 3).

The vaginal epithelium near the plug clearly showed the successive layers of stratum malpighii (basale and spinosum) and corneum with the disjunctum contributing to the plug (Pl. 1, Fig. 4). In the stratum spinosum, the polyhedral epithelial cells with a large round nucleus formed an elaborate system of many short cytoplasmic processes with desmosomes accompanied by bundles of tonofilaments (Pl. 1, Fig. 5 and inset). In the stratum corneum, the cytoplasm appeared devoid of cell organelles and to consist mainly of closely packed keratin filaments.

The cells of the stratum disjunctum, of which the plasma membranes were destroyed, coalesced and ultimately became changed into the structureless layer of the vaginal plug (Pl. 1, Fig. 6). In places, however, there were still some indistinct remnants of the cytoplasmic processes, where deformed desmosomes had an unusually thick, dense intermediate layer (PI. 1, Fig. 6 inset).

In the central core of the vaginal plug in the bats just after copulation (mid- or late October), almost all the spermatozoa showed signs of degeneration characterized by fusion of the plasma and outer acrosomal membranes especially in the cap region (Pl. 2, Fig. 7), and polymorphonuclear leucocytes containing engulfed spermatozoa were seen (Pl. 2, Fig. 8). On the other hand, in the hibernating bats examined in late January, all the spermatozoa in the central core showed loss of the plasma membrane and acrosome and dissociation of the other cell organelles (Pl. 2, Fig. 9), and there were few leucocytes with phagocytosed spermatozoa.

The vaginal plug appeared to be expelled just before or after ovulation; in the specimens collected in April (see Table 1), out of 6 non-ovulated bats ( 3 gonadotrophin-injected, 3 nontreated) 1 non-treated bat had eliminated the plug, and 2 of 4 bats in which ovulation had been induced and which contained a fertilized ovum in the right ampulla had also voided the plug.

\section{PLATE 2}

Fig. 7. Electron micrograph of a spermatozoon in the central core of the vaginal plug in a bat just after copulation, characterized by extensive fusion (arrow-heads) of the plasma and outer acrosomal membranes in the cap and the equatorial regions.

Fig. 8. Polymorphonuclear leucocyte engulfing a sperm head found in the same central core as in Fig. 7.

Fig. 9. The boundary zone between the outer structureless layer and central core of the vaginal plug in a hibernating bat, showing packed dead spermatozoa.

\section{PLATE 3}

Fig. 10. Electron micrograph showing a uterine glandular cavity filled with numerous dead spermatozoa in another bat just after copulation. Note the absence of polymorphonuclear leucocytes.

Fig. 11. Degenerating spermatozoa in Fig. 10 at higher magnification, showing breakdown of the plasma membrane and acrosome cap.

Fig. 12. Light micrograph of the uterine wall of the same hibernating bat as in Fig. 9, showing the glandular cavities filled with many infiltrated polymorphonuclear leucocytes. Toluidine blue.

Fig. 13. Electron micrograph of a polymorphonuclear leucocyte in Fig. 12. Showing the engulfment of sperm fragments. 


\section{Death of spermatozoa and leucocytic infiltration in the uterus}

In the uterus of the bats immediately after copulation, almost all the numerous spermatozoa were found crowded in the cavity of uterine glands (P1. 3, Fig. 10) with a few in the uterine lumen. However, they all appeared to be dead judging from such degenerative signs as breakdown of the plasma membrane and an irregular bent or lost acrosome (Pl. 3, Fig. 11). In spite of the presence of large numbers of the degenerating spermatozoa, few polymophonuclear leucocytes were observed. In the hibernating bats, the glandular cavities contained large numbers of leucocytes engulfing the fragments of spermatozoa (Pl. 3, Figs 12 and 13). Such a leucocytic phagocytosis increased as hibernation continued and persisted until after ovulation in spring.

\section{Discussion}

The huge vaginal plug of Rhinolophus hipposideros was first described by Fries (1879) as a cartilagelike mass in the vagina. It has been suggested that the vaginal plug is mainly composed of mucus ( $R$. ferrumequinum: Rollinat \& Trouessart, 1897) or coagulated secretions of the male urethral gland (R.f. insulanus and R. h. minutus: Matthews, 1937; R. hipposideros: Gaisler, 1966), but it is clear from the present study of $R . f$. nippon that the outer, thick and structureless layer occupying the greater part of the vaginal plug originates from the stratum disjunctum of the vaginal epithelium.

The vaginal plugs of vespertilionine bats are smaller than those of rhinolophids, although they, too, are formed mainly by cornification of the vaginal epithelium (Grosser, 1903; Courrier, 1924; Reeder, 1939; Racey, 1975; Kitchener, 1975; Krishna \& Dominic, 1978). In the noctule (Nyctalus noctula) connective tissue hyperplasia is also involved in the formation of the vaginal plug (Racey, 1975).

The spermatozoa found in the central core of the vaginal plug of $R . f$. nippon are regarded as being accidentally trapped there, and therefore their number cannot be compared with that of spermatozoa introduced into the uterus. The present study confirmed that the spermatozoa in the central core are not active after hibernation because there is obvious loss of structural integrity, and subsequent autolysis or phagocytosis by polymorphonuclear leucocytes. The vaginal plug does not therefore store spermatozoa during hibernation.

The persistence of the vaginal plug in mammals varies with the species (Hadek, 1969). Bats are unusual in that the plug is found in the vagina from autumn until spring, except in a miniopterine bat, Miniopterus schreibersii fuliginosus, in which the vaginal plug is expelled immediately after autumnal copulation followed closely by ovulation and fertilization (unpublished observations). Although the vaginal plugs of some rhinolophids seemed to be maintained throughout the winter and spring until the blastocyst reaches the uterus (Matthews, 1937), that of $R$. f. nippon appears to be expelled just before or after ovulation regardless of whether ovulation is induced by gonadotrophins. The plug plays an important part in preventing a second mating, but cannot be considered to be involved in the elimination of excess spermatozoa from the female tract. Spermatozoa may be eliminated from the female reproductive tract by muscular contractions, enzymic dissolution, phagocytosis by leucocytes or epithelial cells, or the active entry of spermatozoa into the epithelial and subepithelial tissues (Racey, 1975). In the Japanese greater horseshoe bat, in which the principal site of sperm storage is the caudal isthmus but not the uterus (Möri et al., 1982), excess spermatozoa remaining in the uterus die rapidly after copulation, autolyse or are gradually phagocytosed by leucocytes and eventually are eliminated.

Although phagocytosis of dead spermatozoa by leucocytes in the uterus is fairly common among mammals (Mōri \& Uchida, 1980), the vespertilionine bats of temperate latitudes appear to be exceptions. In P. abramus (Uchida \& Möri, 1974), $P$. pipistrellus, $N$. noctula, Myotis nattereri and $M$. daubentoni (Racey, 1975, 1979), the uteri of which are the principal site of sperm storage throughout winter, leucocytes are seldom found. In the rabbit, damaged spermatozoa are easily ingested by leucocytes, but intact spermatozoa are phagocytosed only in the uterus of an oestrous doe, 
suggesting that discrimination by phagocytes is related to some change of the plasma membrane (Bedford, 1965).

Sperm heads have been identified with the light microscope in the uterine gland mucosa of two guinea-pigs (Austin, 1960) and in the uterine epithelial cells of two pipistrelle bats (Racey, 1975). In $R$. $f$. nippon, neither the engulfment of spermatozoa by the epithelial cells nor the entry of spermatozoa into them could be recognized in the uterus, although both the former (Möri et al., 1982) and the latter (unpublished observations) do occur in the oviduct.

We thank Dr S. Arai of our Laboratory and Dr T. Kuramoto of the Akiyoshi-dai Museum of Natural History for their help collecting specimens; Professor E. W. Jameson, Jr, University of California, for comments on the manuscript; and Dr P. A. Racey, University of Aberdeen, for advice and encouragement in the course of this study.

\section{References}

Austin, C.R. (1960) Fate of spermatozoa in the female genital tract. J. Reprod. Fert. 1, 151-156.

Bedford, J.M. (1965) Effect of environment on phagocytosis of rabbit spermatozoa. J. Reprod. Fert. 9, 249 256.

Courrier, R. (1924) Le cycle sexuel chez la femelle des Mammifères. Etude de la phase folliculaire. Archs Biol. 34, 369-477.

Fries, S. (1879) Ueber die Fortpflanzung der einheimischen Chiropteren. Zool. Anz. 2, 355-357.

Gaisler, J. (1966) Reproduction in the the lesser horseshoe bat (Rhinolophus hipposideros hipposideros Bechstein, 1800). Bijdr. Dierk. 36, 45-64.

Grosser, O. (1903) Die physiologische bindegewebige Atresie des Genitalkanales von Vesperugo noctula nach erfolgter Kohabitation. Verh. anat. Ges. Jena 17, 129-132.

Hadek, R. (1969) The vaginal plug. In Mammalian Fertilization, pp. 59-89. Academic Press, New York \& London.

Kitchener, D.J. (1975) Reproduction in female Gould's Wattled Bat Chalinolobus gouldii (Gray) (Vespertilionidae), in western Australia. Aust. J. Zool. 23, $29-42$.

Krishna, A. \& Dominic, C.J. (1978) Storage of spermatozoa in the female genital tract of the vespertilionid bat, Scotophilus heathi. J. Reprod. Fert. 54, 319-321.

Matthews, L.H. (1937) The female sexual cycle in the British horseshoe bats, Rhinolophus ferrumequinum insulanus Barrett-Hamilton and $R$. hipposideros minutus Montagu. Trans. zool. Soc. Lond. 23, 224-267.

Mōri, T. \& Uchida, T.A. (1974) Electron microscopic analysis of the mechanism of fertilization in Chirop- tera. II. Engulfment of spermatozoa by epithelial cells of the Fallopian tube in the Japanese house bat, Pipistrellus abramus. Zool. Mag., Tokyo 83, 163-170. [In Japanese with English abstract.]

Mōri, T. \& Uchida, T.A. (1980) Sperm storage in the reproductive tract of the female Japanese longfingered bat, Miniopterus schreibersii fuliginosus. J. Reprod. Fert. 58, 429-433.

Mōri, T., Oh, Y.K. \& Uchida, T.A. (1982) Sperm storage in the oviduct of the Japanese greater horseshoe bat, Rhinolophus ferrumequinum nippon. J. Fac. Agr., Kyushu Univ. 27, 47-53.

Racey, P.A. (1975) The prolonged survival of spermatozoa in bats. In The Biology of the Male Gamete, pp. 385-416. Eds J. G. Duckett \& P. A. Racey. Academic Press, London.

Racey, P.A. (1979) The prolonged storage and survival of spermatozoa in Chiroptera. J. Reprod. Fert. 56, 391402.

Reeder, E.M. (1939) Cytology of the reproductive tract of the female bat Myotis lucifugus lucifugus. J. Morph. 64, $431-453$.

Rollinat, R. \& Trouessart, E. (1895) Sur la reproduction des chauves-souris. Bull. Soc. zool. Fr. 20, 25-28.

Rollinat, R. \& Trouessart, E. (1897) Sur la reproduction des chauves-souris. Mém. Soc. zool. Fr. 10, 114-138.

Uchida, T.A. \& Mōri, T. (1974) Electron microscopic analysis of the mechanism of fertilization in Chiroptera. I. Acrosomal reaction and consequence to death of the sperm in the Japanese long-fingered bat, Miniopterus schreibersii fuliginosus. Sci. Bull. Fac. Agr. Kyushu Univ. 28, 177-184. [In Japanese with English summary.]

Received 29 October 1982 